\title{
THE ROLE OF THE INTERNATIONAL COMMISSION FOR SUPERVISION AND CONTROL IN VIETNAM IN THE POPULATION EXCHANGE BETWEEN VIETNAMESE STATES DURING YEARS 1954-1955
}

Jarema Słowiak

http://orcid.org/0000-0002-3104-4415

\begin{abstract}
When Geneva Agreements dividing Vietnam were reached in the early morning hours of 21 July 1954, the Article 14(d) of those accords was considered to be a minor, technical one. It guaranteed free movement of people between opposite sides' zones, so they could move to the half of Vietnam they preferred. The authorities in both the South and the North didn't expect more than several tens of thousands of people. Instead, the South was flooded with a vast wave of refugees, numbering in hundreds of thousands. Geneva Conference also established the International Commission for Supervision and Control, composed of India, Canada and Poland, to oversee the implementation of the Geneva Accords in Indochina. One of its most important tasks was to supervise the aforementioned free movement of people. In this article, I would like to show how internal differences between the countries making the ICSC affected the supervision of Article 14(d), particularly in respect of activities of communist side, which actively tried to prevent people from leaving North Vietnam.
\end{abstract}

Keywords: Geneva Agreements, International Commission for Supervision and Control, Migration, Operation Passage to Freedom, Vietnam, Vietnam War.

\section{THE GENEVA CONFERENCE AND THE SPLIT OF VIETNAM}

In 1954 the Indochina War between French and Viet Minh forces reached its climax. After eight long years of exhausting warfare, both sides clashed in decisive battle for the Dien Bien Phu fortress, located in an isolated valley in the north Vietnam from which it took her name. Fierce and merciless combat went on for almost two months, when, after pulling in every possible reserve, communist troops of Viet Minh won, planting their battle standard on the French command post on 7 May 1954. On the very 
next day the Indochina part of Geneva Conference started. The talks dragged on, hindered by the contradicting interests of great powers. In the end, cease-fire agreements were signed, and Final Declaration accepted only around 3 AM on 21 July. ${ }^{1}$

Geneva Accords partitioned Vietnam into two parts: southern, ruled by the prowestern State of Vietnam, and northern, governed by the communist Democratic Republic of Vietnam (DRV), with dividing line set at $17^{\text {th }}$ parallel, where Demilitarized Zone was established. In two years, both parties were to organize the unification elections, which were to decide the fate of whole Vietnam. Troops of both sides were supposed to regroup into designated zones, and ceasefire was implemented in whole country.

What is most interesting and important from the point of view of this paper, Article 14(d) of the Geneva Accords said: "from the date of entry into force of the present Agreement until the movement of troops is completed, any civilians residing in a district controlled by one party who wish to go and live in the zone assigned to the other party shall be permitted and helped to do so by the authorities in that district." 2

This was further reinforced by the Point 8 of Final Declaration of the Geneva Conference: "the provisions of the agreements on the cessation of hostilities intended to ensure the protection of individuals and of property must be most strictly applied and must, in particular, allow everyone in Viet-Nam to decide freely in which zone he wishes to live."

The ensure the proper realization of those agreements, Article 34 of Geneva Agreements established an special, international body: "An International Commission shall be set up for the control and supervision over the application of the provisions of the agreement on the cessation of hostilities in Viet-Nam. It shall be composed of representatives of the following States: Canada, India and Poland. It shall be presided over by the Representative of India."

\section{THE COUNTRIES PARTICIPATING IN THE WORK OF ICSC}

Each of the three countries chosen to cooperate in the International Commission for Supervision and Control had different motivation and reasons to accept the request of Geneva Conference powers.

India was not one of the negotiating powers participating in the Geneva Conference. However, Indian diplomats were constantly present in Switzerland, and were heavily involved in the backstage discussions during the course of whole negotiations, promoting their role of a neutral power that was supposed to help the two hostile blocs in coming to an agreement. British Foreign Office even suspected Krishna Menon, Indian Ambassador to the United Nations and close confidante of prime min-

1 The official date on all documents is 20 July 20 1954, since the French prime minister pledged to resign if agreements were not reached by that date.

2 The time foreseen for troop movement was 300 days. 
ister Jawaharlal Nehru, of being the real force behind the Chinese proposal for the final composition of the ICSC. India's participation in the Supervisory Commission was therefore a logical continuation of this policy. For Indians it was a part of building the world-wide prestige of their young country - the only real neutral power, as they liked to think of themselves. However, at the same time India had very specific political, cultural and economical interests in Southeast Asia, and participation in ICSC was one of ways to protect them. Motives of Polish and Canadian participation in the work of the Commission were a bit more complex.

Canadians came to Vietnam as representatives of the Western World. Canada did not have any vital interests in Southeast Asia at that time, and the proposal to participate in the work of ICSC was greeted in Ottawa without much enthusiasm. While taking part in the work of the Commission was undoubtedly very prestigious, it was also linked with some serious problems and risks. It would mean the need to organize a highly specialized and large delegation of several hundred people, which would put a significant burden on the Canadian military and diplomatic corps. However, what was feared most was the reaction of the United States. Close ally and guarantor of the Canada's security openly manifested dissatisfaction with the results of the Geneva Conference.

In a certain sense Canada fell a victim of her own existing diplomatic activity (fifties were the Golden Age of Canadian Foreign Policy, with crowning jewel of Nobel Peace Prize for minister Lester Pearson in year 1957) and as High Commissioner in London wrote to his superior in Ottawa, "task suggested is certainly ungrateful but I do not see how we can do other than accept it." ${ }^{\prime 3}$ In addition, Canadian worries about American reaction were somehow dispelled when Washington assured Ottawa that they would by no means hold participation in the work of ICSC against their northern neighbor, and in fact were very pleased that it would be Canada that would be a representing the West World in the Commission. In the end, on 28 July 1954, Ottawa decided to respond positively to the invitation, accepting participation in the work of the Commission as her "stern international duty"4 and acknowledging that "there was probably no other Western country in a better position than Canada to work harmoniously and effectively with India". ${ }^{5}$

As Canada had no prior knowledge of Indochina, ${ }^{6}$ it was forced to ask U.S. Department of State for necessary materials about the region. There was also already

3 High Commissioner in United Kingdom to Secretary of State for External Affairs, Telegram 845, July 19, 1954, International Supervisory Commission - Indo-China, ed. G. Donaghy [in:] Documents on Canadian External Relations, vol. 20: 1954, Ottawa 1997, pp. 1676-1677.

4 Ambassador in United States to Secretary of State for External Affairs, Telegram WA-1302, July 24, 1954, Indo-China Supervisory Commissions [in:] Documents on Canadian External Relations, pp. 1686-1687.

5 Extract from Cabinet Conclusions, July 28, 1954, Indo-China, Membership in International Supervisory Commissions for Vietnam, Laos and Cambodia [in:] Documents on Canadian External Relations, pp. 1695-1697.

6 Only Canadian enterprise in Indochina in previous decades was a spy ring formed by a Canadian citizen Laurence Gordon during World War II. L. Sobolew ski, Indochiny Francuskie w polityce Japonii w latach 1940-1945, Warszawa 2011, p. 203. 
aforementioned issue of finding qualified personnel in enough quantity. In addition, Canadians were deeply troubled by Polish participation in the ICSC, foreseeing serious problems in day-to-day functioning of the Commission, as they expected worst from their communist partners, including offensive words, personal insults and using every possible tactic to delay or obstruct the activities of ICSC.?

In contrast to Ottawa, dilemmas tied to the participation in the Commission are hard to find in Polish archives. The order sent from Moscow had to be carried out and the authorities in Warsaw responded affirmatively to the invitation sent by Molotov and Eden on 23 July, only a day after receiving the message from the Conference cochairmen. Preparatory work actually began earlier, on 20 July, so even before the official publication of the Geneva Conference results. Polish People's Republic was not a truly independent state in 1954. Stalin was dead for barely little more than a year, and smaller communist countries were only cautiously beginning to form their own foreign policies in the framework imposed by their Soviet overseers. Poland was no exception. However, as the strongest and largest of the USSR satellite states, Polish People's Republic had an ambition to play a much larger role in the world than fellow fraternal states from the progressive bloc. Participation in the work of esteemed international bodies, like ICSC, was perceived as a fine way of gaining prestige and recognition on the world stage. What's more, Warsaw deemed that their participation in the work of the Commission was enhancing the Polish position in the Eastern Bloc itself, since it meant in a way that Poland was given a task to help and protect the newly-born communist state of the Democratic Republic of Vietnam. Last but not least, Poles already had a bit of international experience in the matter, because since year 1953 they were part of the Neutral Commission in Korea.

However, being suddenly faced with the obligation to send a huge delegation to the other side of the world, Poland was faced with various challenges of such diverse nature as transport, proper uniforms and equipment, and health issues. But the key and almost impossible challenge was finding proper number of English and French speakers. In the realities of Polish fifties, still in Stalinist period, simple knowledge of languages from the enemy camp was enough to merit attention from the dreaded security apparatus. At the same time, only people deemed to be politically reliable and loyal to the Party were allowed to go abroad. The problem was even more severe in case of the Polish Army officers, essential for the ICSC work, who rarely knew any foreign language at all (beside Russian). The political line of the Polish Delegation was based on the defense of the interests of the communist side. However, despite Canadian worries, the documents do not show any remote control from Moscow or Warsaw. Polish ambassadors were given instructions in Warsaw and consulted with government authorities in Moscow and Beijing along their way to Indochina, but the decision-making on the spot was left to them, with trust that they would know how to properly support the people's side. Until the escalation of American intervention

Secretary of State for External Affairs to Commissioner, International Supervisory Commission for Vietnam, August 24, 1954, Dear Mr. Lett [in:] Documents on Canadian External Relations, pp. 1716 1724. 
during Kennedy administration, Kremlin perceived Indochina as unimportant periphery of the global struggle against capitalism. Thus, the Polish representative in ICSC could be left without direct supervision, as long as he abided with the general communist line of interests. Interestingly, one of the main priorities of the Polish delegation was "defense of democratic freedoms" throughout Vietnam, since in the evaluation of the Communists, "even the existence of formal democracy (in the bourgeois sense) ensures the victory of the popular forces." ${ }^{8}$ Of course this was really true only in the South Vietnam. In the Democratic Republic of Vietnam the role of the Polish Delegation was to act as a shield for their communist brethren and their activities.

Same as Canadians, Poles assumed that the key to success would be to gain the backing from the delegate of India. In the instructions issued prior to the first joint conference of the ICSC members, Polish Delegate was clearly told that "tactics requires that the Indians should not be antagonized." Communists hoped that by applauding the openly declared neutrality and anti-colonialism of Indians, they would be able to pull them into anti-American positions.

\section{OPERATION PASSAGE TO FREEDOM}

As it was mentioned at the very beginning, most sides assumed that free movement of people between both zones would be one of the technicalities of ceasefire agreements, simply a way to peacefully evacuate government servants, soldiers, and their families from the North, and Viet Minh partisan units from the South. ${ }^{10}$ However, South Vietnamese prime minister, Ngo Dinh Diem, with the extensive support of United States, France and Great Britain, decided to bring as many of his compatriots to the South as possible. He had several reasons for that. Since most of his political backing came from Catholic regions in the North Vietnam, he was in danger of losing that support. At the same time, there were fears about communist reprisals against Catholics in the North. Mass movement of people from North to South was also supposed to be a political statement, legitimizing Ngo Dinh Diem's rule. Last but no the least, every movement of people from north to south weakened communist North and strengthened pro-western South.

South propaganda campaign, sponsored and supported by Americans, was multifaceted. Undercover agents were sent to market squares in the North, to spread various rumors of imminent calamities that will soon visit the communist-ruled country, for example they claimed that Chinese were coming back (Chinese left a lot of bad

8 Report by Przemysław Ogrodziński from 19 September 1954, coming from the Polish Ministry of Foreign Affair Archives. Raport nr. 2, zespół 12, wiązka 77, teczka 1327, MKNiKw Wietnamie (Raporty delegacji polskiej) 1954, Archiwum Ministerstwa Spraw Zagranicznych [hereafter AMSZ], Warszawa.

9 Internal memorandum of Polish Ministry of Foreign Affairs from 20 August 1954. Towarzysz Minister Dr. St. Skrzeszewski, w gmachu, z. 12, w. 62, t. 1226, MKNiK w Indochinach (Sprawy organizacyjno-kadrowe w Komisji) 1954, AMSZ, Warszawa.

10 R. Jasica, Problem wietnamski. Aspekty prawne i polityczne, Katowice 1977, pp. 124-125. 
memories when they occupied northern Vietnam right after World War II), or that the Americans will bomb whole country after the 300 days. Local astrologers were paid to publish predictions about great misfortune that will befell the North. Catholics were urged to move south with slogans like "the Virgin Mary has departed from the North" and "Christ has gone south."11 This propaganda was aided by local priests, and often whole villages decided to move. Beside the religious aspect, the relocation was also motivated by the fear of the reprisal - Catholic communities were most anticommunist and pro-French part of society in the North Vietnam, and after Dien Bien Phu and Geneva Conference, dreaded bloody retribution from the victorious Viet Minh.

Efforts of Vietnamese were aided by Americans led by colonel Edward Lansdale, sent to Vietnam by CIA, an officer experienced in propaganda and psy-ops from his service in Philippines, where he helped government forces to quell Huk uprising. ${ }^{12}$ Lansdale became close advisor to Diem and soon his personal friend, and aided him extensively in next few years. However, while the volume of American aid and counsel was quite high, it's influence should not be overestimated. Older literature tends to paint Lansdale as a true mastermind behind the success of operation Passage to Freedom. More recent publication tend to emphasize the complexity of the factors behind the whole enterprise, and also stress the personal role of Ngo Dinh Diem in both encouraging the migration of his compatriots, and the way they were settled in the South Vietnam. ${ }^{13}$

Those activities were of course countered by Viet Minh authorities in the North, who for example warned refugees that Americans will cook and eat them, or that they would open cargo doors of their ships on high seas and drown everybody..$^{14}$ However, compared to the efforts of the other side, the communist response was weak and lacked focus. In addition, despite Viet Minh leadership orders, some local commanders and political cadres forcefully prevented people from leaving and organized show trials of local notables and priest, thus reinforcing fears of local population and validating Southern propaganda.

One additional factor also probably played important role in convincing people to move from North to South Vietnam: fear of famine. Years of warfare devastated Red River Delta and whole Tonkin area. Fields were unattended, essential infrastructure

11 S. Jacobs, Cold War Mandarin: Ngo Dinh Diem and the Origins of America's War in Vietnam, Lanham 2006, p. 56.

12 More about Huk uprising in: L. M. Greenberg, The Hukbalahap Insurrection: A Case Study of a Successful Anti-Insurgency Operation in the Philippines, 1946-1955, Washington 1987, pp. XI + 159.

13 For traditional narration about Lansdale see: K. Ruane, War and Revolution in Vietnam, 1930-75, London-Bristol 1998, p. 38; M. B. Young, J. Fitzgerald, A. T. Grunfeld, The Vietnam War: A History in Documents, Oxford-New York 2003, p. 41; M. Isserman, Vietnam War, New York 2003, pp. 23-25. For more recent evaluation of Diem's and Lansdale's roles, see: E. Miller, Misalliance: Ngo Dinh Diem, the United States and the Fate of South Vietnam, Cambridge-London 2013, p. 420.

14 Both American and French navies extensively used LST (Landing Ship, Tank), equipped with large doors and a ramp in the bow, which allowed them to dock and set off without port facilities. R. B. Frankum, Operation Passage to Freedom: The United States Navy in Vietnam, 1954-1955, Lubbock 2007, p. 202. 
destroyed or neglected, and the ability of Viet Minh government to efficiently manage the restoration of agriculture and the distribution of food was still untested. In addition, North was always dependent on the southern rice basket of Mekong Delta, Saigon government was promising grain, tax exemptions, farm animals and land to cultivate, while American $89 \$$ hangouts for refugees were higher than a yearly $85 \%$ income of average Vietnamese. Last but not the least, the memory of last mass starvation in years 1944-46 was still painfully fresh in Red River Delta. ${ }^{15}$

In the end, we do not know the exact number of people that moved from North to South Vietnam. According to the COMIGAL, ${ }^{16} 768,672$ refugees were transported by air and sea by French, American and British ships. In addition, Saigon government estimated that around 109,000 additional people moved to the South by their own means. According to the ICSC documents, 892,876 refugees evacuated from North, and only 4,269 moved in other direction. ${ }^{17}$ The exact number is impossible to determine, since on the one hand, many people moved on their own, without the government aid and ICSC supervision. On the other hand, there were known cases of crafty individuals who migrated several times, each time collecting government and US aid for refugees. The actual number of refugees who moved south could exceeded one million, and it would be even higher if it were not for the communist authorities actively preventing people from leaving. ${ }^{18}$

\section{ROLE AND THE ACTIVITIES OF THE ICSC}

The international commission established in Geneva occupied a peculiar position in Vietnam - with no legal tools to compel or influence the governments it was supposed to supervise and control, ICSC could only point out to them potential Geneva Agreements violations. The only stick in the Commission's possession was a possibility of sending a letter to Geneva Conference co-chairmen (USSR and Great Britain) to inform them about the accords violation and urging them to act.

However, especially in the first years of ICSC existence, both Vietnamese states wanted to avoid negative publicity associated with potential Geneva Agreements violations, and so even mere presence of the Commission officials sometimes was enough to prevent them from said violations. As it was already mentioned, most of the human traffic was from North to South, thus most incidents and problems appeared in the northern Democratic Republic of Vietnam. Communist cadres, especially on local level, were not too keen to allow people to leave, especially on the scale that emerged in the fall of 1954. This was both from ideological reasons (aban-

15 S. Jacobs, Cold War Mandarin, p. 133. About the importance of fear of hunger in: Mieczysław Maneli, War of the Vanquished, New York-Evanstone-San Francisco-London 1971, pp. 38-40.

16 The South Vietnamese government agency responsible for the migration.

17 R. Jasica, Problem wietnamski, p. 140.

18 M. Moyar, Triumph Forsaken: The Vietnam War, 1954-1965, Cambridge 2006, pp. 39-40. 
doning communist country) and more down-to-earth ones (people leaving en masse put great strain on the young country's economy).

Obstructions created by the communist administration took various forms: lack or suppression of information for the people about the possibility of migration to the South, refusal to issue travel permits, obstructions in access to offices issuing said permits, and so on. The communists also tried to prevent any uncontrolled contact of the population with ICSC members, with the exception of selected cadres, who orchestrated staged protests and delivered petitions, listing real and imagined crimes committed by the French and their allies.

Without surprise, the attitude of Commission members to the human migration from North to South Vietnam was not unanimous. From the Polish Delegation point of view, Southern Vietnamese, French and Americans were bending the spirit of Geneva Agreements with their insistent and misleading propaganda, especially with the prospect of upcoming unification elections, which made any escape from the Communists to the South pointless. Polish Delegation members advised and cooperated with DRV authorities, at times going very far outside of their nominal role in the Commission. ${ }^{19}$

The Commission operated in the North Vietnam with the help of seven fixed teams, and variable number of mobile teams, sent ad hoc to conduct investigations of reported violations. Such group typically consisted of three officers from member countries, ${ }^{20}$ French and DRV liaison officers, and interpreters, also provided by both sides.

A good example of such a team's activity could be the trip of the Mobile Group No. 17, which on 27 November-3 December 1954 examined the application of the Article 14 (d) of the Geneva Agreements in the village of Phat Diem and other surrounding villages. ${ }^{21}$ The team wanted to check if local authorities granted permits to priests and nuns who have expressed their desire to move South, present in Phat Diem; to ascertain the time period for which the permits were issued; to examine and elucidate the difference between the number of permits and number of permits previously reported to have been issued; to ascertain if local authorities are prepared to give financial assistance in needy cases to cover transportation costs and report about the number of persons who do require such financial assistance.

Phat Diem was actually a place where nearly 10,000 refugees congregated in early October 1954, and some of the local priests were arrested by communist for

19 Mieczysław Maneli, the legal adviser of the Polish Delegation, recalled about special conferences held with provincial and district authorities: "I took part in it, not in my capacity as the legal and political adviser, of the Polish delegation, but as a representative of the friendly Polish Workers' party and specialist on the questions of international law and foreign policy arising out of the Geneva Accords." M. Maneli, The War of the Vanquished, transl. from the Polish by M. de Görgey, New York 1971, pp. 41-42.

20 Polish officers were usually accompanied by Polish translators, both because of their lack of language skills, and as a way to control each other.

21 Report of 17 Mobile Team (Reconstituted) on the Application of Article 14(d) of the Geneva Agreement in the Village of Phat Diem And Surrounding Villages, z. 12, w. 92, t. 1404, MKNiK $w$ Wietnamie. Raporty Grup MKNiK w Wietnamie (w jęz. angielskim), oraz projekt instrukcji dla grup $w$ Wietnamie. 1954-55, AMSZ, Warszawa. 
their pro-migration "propaganda." Only after the ICSC mobile team intervention, local authorities transported 8,268 people on motor boats to the French evacuation zone. ${ }^{22}$ Mobile Grup No. 17 was also supposed to check if there were still any people in the town who wanted to go to the South.

The team contacted local authorities, and after obtaining information that Pham Diem district is sub-divided into four communes, planned its activities. At this point ICSC personnel knew about 615 people that wanted to go South who placed 104 petitions in petition boxes in the district. The plan was as follows: one commune will be visited by the team every day, its northern part in the morning and southern in the afternoon; the security personnel accompanying the team should be reduced to minimum, and should not move ahead of the team, to ensure the free access for people; local authorities were to be informed one day ahead so that information about the tour could be passed to respective communes.

On the first day, the team wanted to visit the cathedral to ensure that people gathered there knew about new method of applying for permits. ${ }^{23}$ However, they were stopped by a crowd, who demanded ICSC team to listen to their complains. After one hour the chairman suggested that any further complains should be put up in the form of a petition and requested the crowd to disperse and allow the team to proceed to their original objective. Despite that, gathered people did not move, and after local authorities failed to disperse the crowd, the team decided to return to its place of residence.

The cathedral was reached on the next day, where the team noticed a number of soldiers. Local authorities assured that military was present only to prevent the people from gathering like the day before, however nobody approached the ICSC personnel to express their desire to migrate South.

On 29 November the team went to the office issuing the travel permits, and met there with the heads of communes, to make sure they were aware of the existing procedure for obtaining the permits. The next day ICSC personnel toured both parts of Luu Phuong - Phat Diem commune. The security detail was reduced to minimum and not allowed to move ahead of the team. In effect, twenty seven families, consisting of 194 people came forward and proclaimed their desire to move South.

On 1 December ICSC inspected the commune of Thuong Kiem. Twenty nine families consisting of 198 members came to see the team and declared their willingness to go to the South. Three of those families requested financial help. In addition, 72 nuns from the cathedral compound and local hospital also showed their desire to proceed south. The next day ICSC visited the commune of Cong Van. Nine families

22 First Interim Report of the International Commission for Supervision and Control in Vietnam, August 11, 1954 to December 10, 1954, z. 12, w. 96, t. 1400, M.K.NiK w Wietnamie. Raport okresowy $1954 r$.

${ }^{23}$ Earlier joint application was rejected by the local authorities "as being irregular." Report of 17 Mobile Team (Reconstituted) on the Application of Article 14(d) of the Geneva Agreement in the Village of Phat Diem and Surrounding Villages, z. 12, w. 92, t. 1404, MKNiK w Wietnamie. Raporty Grup MKNiK w Wietnamie (w jęz. angielskim), oraz projekt instrukcji dla grup w Wietnamie. 1954-55, AMSZ, Warszawa. 
consisting of 47 members came forward and expressed their desire to move to the South, and three families requested financial help. People from this commune informed the team that they were told by priests and nuns that there will be a war and atomic bomb will be used, and were pressed in such way to go south. ICSC personnel assured them that should have no fear and make their own decisions not paying attention to any external propaganda. The team also faced constant demonstrations against the French interpreter, Mr. Van, assigned to it, with people accusing him of committing atrocities whilst being a priest in Phat Diem. However, there were no incidents and demonstrators, while constantly present, were kept away from the team. ${ }^{24}$

On the last day, the team toured the fourth commune named Trung Trac. Nobody from this place expressed any desire to move to the South. At the meeting with the Chairman of the Administrative and Military Committee of Phat Diem, the team conferred about the possible financial help for the families who requested such assistance to move south. After that the team returned to its place of residence and sent a signal to the International Commission asking for the withdrawal after the completion of assigned task. However it was ordered to stay in the Phat Diem until the end of the December. In that period the team provided assistance in solving the problem of travel permits which appeared between the local authorities and some of the priests.

Overall, it would seem that the ICSC team did not found anything really disturbing in the Phat Diem and its surrounding communes, perhaps with the exception of the travel delay caused by the crowd during the first day. General public seemed informed enough about the Article 14(d) of the Geneva Agreements, the team's freedom of movement was generally unrestricted, local authorities were cooperative, and the ICSC personnel was satisfied with the organizational side of issuing of the travel permits. However, there is an additional document attached to the report, which sheds a bit different light on the situation in Phat Diem area.

As we can read in the first paragraph of the Observations and Comments by the Canadian Member, "the Canadian member feels that the report does not adequately deal with all of the aspects that have to do with the application of Article 14(d) in Phat-Diem area..." ${ }^{25}$ As the author points out, the team was not really able to check if the permit office was easily accessible, since even though local authorities reported each day the number of permits issued on that day, ICSC personnel never saw any recent permits, or people actually obtaining them.

The Canadian officer also had strong doubts about local authorities providing any actual support for the families requesting assistance in moving south. Also he felt that "far from assisting the team to do its job of finding out how many wanted to go south, the local authority used a number of stratagems to prevent those people from getting to us. ${ }^{26}$ In the opinion of author, the crowd that blocked the team's way on the

24 These demonstrations were occurring all the time from the day the ICSC team reached the cathedral compound on 29 November. Ibid.

${ }_{25}$ Appendix "B", Observations and Comments by the Canadian Member, z. 12, w. 92, t. 1404, $M K N i K$ w Wietnamie. Raporty Grup MKNiKw Wietnamie (w jęz. angielskim), oraz projekt instrukcji dla grup w Wietnamie. 1954-55, AMSZ, Warszawa.

26 Ibid. 
November 27 could be easily dispersed by the accompanying guards, who however did not act when they were requested to. The demonstrations mentioned earlier, directed at French Union Forces interpreter, were instigated by "in most cases the same individuals." ${ }^{27}$ The Canadian officer recognized one young individual on several occasions, each time in different clothing, and at one point dressed as and standing with local administrative cadre.

When it came to the team request to not allow security guards to go ahead of it, in the Canadian member opinion it was kept in effect for only few hours, and not whole tour, like the main ICSC report would suggest. What's more, all the time the team was preceded by the local administrative cadres, moving ahead and on both sides along the ICSC personnel. On several occasions both Canadian officers present observed those cadres dispersing or holding back people that were trying to approach the team. Most of the time "it was done so quickly and furtively that it was impossible to bring the fact to the attention of the Chairman of the team in time, ${ }^{\prime 28}$ and only in some rare cases the people were able to reach the team. ${ }^{29}$

The Canadian member also wondered, how was it possible that every person that had physical difficulty approaching the team turned out to be someone that wanted to go South, while people wishing to complain against local clergy were present practically all the time along the team's route. The Canadian officer ended his document with observation that during the team's visit to cathedral compound, he noticed numerous armed guards around one of the buildings. When the team was nearby, a nun tried to leave the structure and approach the ISCS personnel, however she was instantly pushed back inside by the armed guards. Again, the incident was too fast to be observed by the Chairman of the team.

As we can see, not everything was as normal and dull as the main ISCS team report would suggest. However the situation in Phat Diem area was actually quite typical. Local population knew the propaganda coming from the South and was encouraged to migrate by the local clergy, who were also moving south. While not everybody wanted to move, the number was certainly higher than local communist cadres wanted to admit or accept. People were discouraged or simply not allowed to leave the area and move to evacuation points. At the same time, those who were able to evade local cadres and reach ICSC team were registered and could hope to be allowed to migrate, since they managed to appear on the radar of the Commission. However, as we could read in Canadian member report, not everybody were so lucky. It is also worth to remember that Phat Diem was quite peaceful on the average, in some places communist troops fought with the local people and forced them to remain only with the threat or the actual appliance of violence.

27 Ibid.

28 Ibid.

29 "On another occasion four women could be seen, in the clear, some 30 meters on the other side of a 15-meter wide canal. A man dressed in the fashion of the administrative cadre personnel was with them trying to convince them to go back. The women ignored him for a while and finally shouted across to the team, one of them reached the team walking up to her chest across the canal." Ibid. 
In much more known incident in the town of Ba Lang that took place at the start of 1955, local fishermen who came into contact with French sailors were arrested by communist authorities. In turn, local population turned against the soldiers and administration, disarmed them and occupied the cathedral compound in Ba Lang. The stand-off came to end only after large Viet Minh military reinforcements arrived on 8 January, and arrested more than 200 people. The French side requested ICSC team to be sent to Ba Lang even before the incident, foreseeing the troubles that could rise there due to large numbers of refugees converging in the town cathedral compound grounds by the end of 1954. However, the dispatch was delayed until 3 January by the DRV Liaison Officer, and even then, the team was kept by armed guards in the provincial capital of Thanh-Hoa ${ }^{30}$ until 8 January, when communist authorities already managed to quell all resistance. ${ }^{31}$

Interesting regularity emerges from ICSC documents: the most vigilant members of mobile teams in the DRV were the Canadians, which is not surprising since they were the ones most interested in spotting potential Geneva Agreements violations by the communist side, and were especially sensitive about the plight of fellow Christians ${ }^{32}$ during the period of free movement.

The Indian chairmen in the mobile teams were clinging to their ideal of neutrality and impartiality, which meant most of the times they intervened only when personally faced with undeniable violation of Geneva Agreements.

It was quite different story with the Polish members of ICSC. They were no less perceptive than their Canadian colleagues. Actually, they had to be even more watchful, since in their role of the shield of the communist actions, they had to spot or even foresee potential violations of Geneva Agreements before other team members. If the information about such an event would reach the Commission, the Poles used every possible trick to give time and possibility for the North Vietnamese to clean up after their illegal activities. As the ambassador Sherwood Lett ${ }^{33}$ confided in his letter to Lester Pearson:

A month's close association daily with the Polish Ambassador, and his subordinates, has convinced me that whatever his attitude and instructions may have been in the early stages of the Commission's work, he is definitely now playing the Communist game of obstruction, evasion, stalling, double talk, legalistic and technical objections and any other tactic he can employ to assist the D.R. authorities to carry out the provisions of the Geneva Agreement to the exclusive

30 Around $40 \mathrm{~km}$ from Ba Lang.

31 The ICSC final report was critical both about the treatment of the team by local authorities and the communist actions that led to the confrontation (refusal to issue travel permits). However, thanks to the efforts of the Polish member, the team also put a share of the blame on the French, claiming that the presence of their ship "show an unnatural interest on the part of the French authorities in this area." Press Communique, Ba Lanh Incident, z. 12, w. 77, t. 1330, MKNiK w Wietnamie (Sprawozdania z działalności Komisji w jęz. angielskim) 1955, AMSZ, Warszawa.

32 The freedom of movement was the main axis of the Canadian policy inside the Commission, both because of the US pressure, but also the home public opinion, concerned about the fate of Christians under the communist rule. J. Słowiak, "Working with the Enemy: Polish Perception of the Canadian Delegation in the International Commission for Supervision and Control in Vietnam," TransCanadiana: Polish Journal of Canadian Studies / Revue Polonaise d'Études cannadiennes 2015, t. 7, pp. 54-55.

33 The first chief of the Canadian Delegation. 
advantage of Communist policy. I would go so far at the moment to say that I think that he or someone of his political views is either directly or indirectly consulting with and advising the new D.R. regime. ${ }^{34}$

Indeed the Poles were both advising and regularly consulting with Hanoi leadership, and also held no sentiment for the people willing to escape the youngest member state of the international communist family. In the report sent to Warsaw by the Polish deputy representative to ICSC, he describes how Polish Delegation tried to present the problem of travel permits issuing in Phat Diem as purely caused by authorities on local level, to shield the DRV central authorities in Hanoi from accusations of deliberately violating the Article 14(d). Poles managed to convince the Indian Delegation to such interpretation, which along with various other legal tricks resulted in the final report only mildly reminding communist side to put more effort into implementation of the arrangements from Geneva. ${ }^{35}$

In other incident, the ICSC was faced with French request to intervene to protect 4,000 members of their former irregular units in the region of Pakha, who were being attacked by DRV military. However, as Polish report noted:

Our tactics on the freedom committee consisted above all of multiplying doubts about particular facts and the possibilities of using individual articles, so we could drag the whole issue as much as possible, thereby giving our friends the chance to actually solve the problem - that is to liquidate the band, purposefully left behind by the French. ${ }^{36}$

As we can see, the Polish Delegation indeed was "playing the Communist game of obstruction, evasion, stalling, double talk, legalistic and technical objections." It is interesting to note however, that while complaining about the Polish attitude, the chief of Canadian Delegation was more concerned with the other member of the Commission: "I am not so concerned with Polish moves which can now be predicted quite easily in most cases as with the Indian attitude." ${ }^{\prime 37}$

\section{CONCLUSIONS}

Despite of internal disputes and conflicting interests of its members, International Commission for Supervision and Control did as much as it could to fulfill the mandated task of supervising the free movement of people guaranteed by the articles of

34 Commissioner, International Supervisory Commission for Vietnam, to Secretary of State for External Affairs, December 2, 1954, Dear Mike [Pearson] [in:] Documents on Canadian External Relations, pp. 1767-69.

35 Sprawozdanie z pracy Komitetu Swobód za okres styczeń-luty i dekadę marca 1955, z. 12, w. 77, t. 1333, M.K.NiK w Wietnamie (Raporty okresowe delegacji polskiej) 1955 r., AMSZ, Warszawa.

36 Ibid.

37 Commissioner, International Supervisory Commission for Vietnam, to Secretary of State for External Affairs, December 31, 1954, Indian and Polish Attitudes [in:] Documents on Canadian External Relations, pp. 1788-1790. 
the Geneva Agreements. In many cases the simple presence of international observers was enough for the local communist authorities to allow people to leave, just like absence of said observers sometimes doomed hopeful migrants to remain. ICSC could do not much more since it had no authority over the sides of the armistice and it effectiveness depended on their good will - it could only appeal to them or inform the Chairmen of the Geneva Conference about any violations of the accords or obstructions of ICSC work.

In the end, despite of the efforts of Democratic Republic of Vietnam authorities, ardently aided by the Polish Delegation in the ICSC, vast wave of migrants did move to the South, with over eight hundred thousand persons registered in the Commission official documents, which were by no means the final number of people that decided to leave the North Vietnam during tumultuous period of 1954-1955.

\section{BIBLIOGRAPHY}

\section{Primary and Printed Sources}

Archiwum Ministerstwa Spraw Zagranicznych w Warszawie (Polish Ministry of Foreign Affairs Archive in Warsaw)

Documents on Canadian External Relations, vol. 20: 1954, Ottawa 1997.

The National Archives (UK)

\section{Books and Articles}

Frankum, R. B., Operation Passage to Freedom: The United States Navy in Vietnam, 19541955, Lubbock 2007.

Greenberg, L. M., The Hukbalahap Insurrection: A Case Study of a Successful Anti-Insurgency Operation in the Philippines, 1946-1955, Washington 1987.

Isserman, M., Vietnam War, New York 2003.

Jacobs, S., Cold War Mandarin: Ngo Dinh Diem and the Origins of America's War in Vietnam, Lanham 2006.

Jasica, R., Problem wietnamski. Aspekty prawne i polityczne, Katowice 1977.

Maneli, M., The War of the Vanquished, transl. from the Polish by M. de Görgey, New York 1971.

Miller, E., Misalliance. Ngo Dinh Diem, the United States and the Fate of South Vietnam, Cambridge-London 2013.

Moyar, M., Triumph Forsaken: The Vietnam War, 1954-1965, Cambridge 2006.

Ruane, K., War and Revolution in Vietnam, 1930-75, London-Bristol 1998. 
Słowiak, J., "Working with the Enemy: Polish Perception of the Canadian Delegation in the International Commission for Supervision and Control in Vietnam," TransCanadiana: Polish Journal of Canadian Studies / Revue Polonaise d'Études cannadiennes 2015, t. 7, pp. 54-55.

Sobolewski, L., Indochiny Francuskie w polityce Japonii w latach 1940-1945, Warszawa 2011.

Young, M. B., Fitzgerald, J., Grunfeld, A. T., The Vietnam War: A History in Documents, Oxford-New York 2003. 